UDK:343.222

343.796

Prethodno priopćenje Primljen: 14. svibnja 2018. Prihvaćen: 15. lipnja 2018.

Izv. prof. dr. sc. Damir PRIMORAC,

Pravni fakultet Sveučilišta u Mostaru

damir.primorac@primorac-partners.com

Maja BUHOVAC,

doktorandica Pravnog fakulteta Sveučilišta u Mostaru

buhovac.maja@gmail.com

\title{
IZRAVNA NAMJERA KAO UVJET KAŽNJIVOSTI ODGOVORNIH OSOBA ZA DELICTA PROPRIA
}

Sažetak: Radom se problematizira pitanje utvrđivanja kaznene odgovornosti odgovornih osoba koje se javljaju kao počinitelji niza kaznenih djela iz posebnog dijela Kaznenog zakona Federacije BiH, osobito gospodarskih. Za utvrđivanje njihove krivnje, osim složenih radnji dokazivanja zbog prirode gospodarskih kaznenih djela, na nekim mjestima zakon propisuje $i$ izravnu namjeru. Ona se ogleda u znanju odgovorne osobe o osobnom svojstvu te znanju o protupravnosti djela. Međutim, kod delicta propria, kakva su većina gospodarskih kaznenih djela, utvrđivanje znanja kao uvjeta kaznene odgovornosti odgovorne osobe relativizira mogućnost kažnjavanja iste, što vodi pravnoj nesigurnosti koja povlači za posljedicu $i$ ostavljanje nesankcionirane odgovorne osobe te pravne osobe u kojima odgovorne osobe predstavljaju jednu vrstu alter ega. Takve de lege lata odredbe rezultat su dinamičnih izmjena kaznenog zakonodavstva kao posljedica novih pojavnih oblika kriminaliteta, kaznenih djela $i$ njihovih počinitelja. Stoga, rad problematizira nekoliko naizgled odvojenih, ali u stvari nužno povezanih pitanja koje je potrebno uskladiti. Na temelju analize pojedinih instituta kaznene odgovornosti, vrsta kaznenih djela s obzirom na krug počinitelja, te napose pojma odgovorne osobe, rad pretendira da ponudi de lege ferenda rješenja u odnosu i na sami pojam odgovorne osobe, ali osobito uvjete i način utvrđivanja njezine kažnjivosti. Cilj je dogmatičkim pristupom ovim institutima olakšati put pronalaženja i otkrivanja počinitelja teških kaznenih djela iz 
posebnog dijela Kaznenog zakona, te na taj način omogućiti postizanje svrhe kažnjavanja $i$ svrhe izricanja kaznenopravnih sankcija.

Ključne rïječi: odgovorna osoba, kaznena odgovornost, izravna namjera, neizravna namjera, delicta propria, gospodarska kaznena djela, pravne osobe.

\section{Uvod}

Suvremeno kazneno pravo nužno prati dinamične društvene promjene, što rezultira stalnim naporima da se normativni okvir i sudska praksa harmoniziraju. Zbog toga su nastala i neka prijeporna pitanja čak i kod onih klasičnih postulata kaznenog prava koji podliježu potrebi drukčijeg teleološkog pristupa. Kaznena odgovornost temeljni je institut kaznenog materijalnog prava, te o njenom pojmu u teoriji kaznenog prava postoji nekoliko tumačenja. Ona primarno predstavlja skup subjektivnih uvjeta kojima se označava psihičko stanje počinitelja i njegov odnos prema kaznenom djelu, odnosno onih subjektivnih uvjeta koji karakteriziraju počinitelja kaznenog djela kao ubrojivog i krivog. Dakle, to je genusni pojam koji označava ubrojivost i krivnju (vinost) u svom jedinstvu, iz čega proizlazi da je kaznena odgovornost subjektivna, psihička kategorija. Osim takvog užeg ili subjektivnog shvaćanja, u pravnoj teoriji postoji i šire ili objektivno-subjektivno shvaćanje kaznene odgovornosti. Prema tom shvaćanju, kaznena odgovornost se sastoji od tri elementa: 1) kaznenog djela (objektivnog elementa), 2) ubrojivosti i 3) krivnje (subjektivnih elemenata). Kaznena odgovornost zaista pretpostavlja postojanje kaznenog djela jer se problem utvrđivanja kaznene odgovornosti postavlja tek nakon što je počinjeno društveno opasno, protupravno i u zakonu određeno djelo kao kazneno djelo za čijeg je počinitelja predviđena kazna. U teoriji kaznenog prava se, pak, mogu naći i takva shvaćanja prema kojima je središnji institut ove grane prava krivnja, a kaznena odgovornost predstavlja samo konstataciju, tj. utvrđivanje da neka osoba ispunjava uvjete za krivnju. Kaznena odgovornost je tako samo posljedica činjenja kaznenog djela, kao što je građanskopravna odgovornost samo posljedica činjenja građanskopravnog delikta (prouzročenja štete). Prema takvom shvaćanju, kaznena odgovornost je samo tehnički termin koji ukazuje da je neka osoba počinila kazneno djelo i da je za njega odgovorna. To znači da je kaznena odgovornost pojam koji ima samo deklarativni, a ne suštinski karakter. ${ }^{1}$

\footnotetext{
${ }^{1}$ PETROVIĆ, B., JOVAŠEVIĆ, D., Krivično/Kazneno pravo Bosne i Hercegovine - opći dio, Pravni fakultet Univerzitet u Sarajevu, Sarajevo, 2005., str. 197-198.
} 
Premda u teoriji kaznenog prava postoje različita shvaćanja prema kojima se ovaj pojam smatra suvišnim te ga treba zamijeniti samo pojmom krivnja, kaznena odgovornost je jedna vrsta odgovornosti i zauzima značajno mjesto u pravu uopće. Osim toga, imajući u vidu druge vrste odgovornosti (administrativnu, građanskopravnu), kaznena odgovornost je najstroža. Stoga je njezine elemente potrebno dogmatički tumačiti i pravilno implementirati prema vrsti kaznenih djela i njihovih počinitelja. U tom smislu, ovaj rad pretendira da ukaže na određene probleme koji se javljaju pri implementaciji pojedinih oblika krivnje kod određenih osoba za određena kaznena djela. Svi sastojci krivnje čine zajedno kaznenu odgovornost i za njihovo utvrđivanje potrebno je poznavati materijalnopravne elemente iste, kako bismo deduktivnom metodom mogli pronaći konkretna rješenja za konkretne slučajeve.

\section{Krivnja i namjera}

Kako je u uvodnom dijelu kazano, kaznenu odgovornost u užem smislu čine krivnja i ubrojivost. Zakon definira pojam krivnje, ali ubrojivost ne definira. Razlog tomu je što se ubrojivost kod počinitelja presumira, pa stoga Kazneni zakon Federacije $\mathrm{BiH}^{2}$, kao i većina poredbenih kaznenih zakonodavstava, propisuje neubrojivost. Ubrojivost je, najkraće definirano, sposobnost za krivnju. Dakle, kako bi se utvrdila krivnja počinitelja, mora biti izvan svake sumnje da se on u vrijeme kad je počinio određeno djelo mogao smisleno opredijeliti, odnosno kontrolirati svoje postupke. S druge strane, krivnja, osim nehaja, uključuje namjeru koja se dijeli na izravnu i neizravnu. Za ovaj rad osobito je važno utvrditi kako se sadržaj namjere kao sastojka krivnje manifestira kod određenih vrsta kaznenih djela, odnosno njihovih počinitelja s posebnim svojstvom.

\subsection{Krivnja}

Koncept krivnje oduvijek je pitanje kaznenopravnih rasprava. Da bi se odgovorilo na pitanje što opravdava izricanje prijekora počinitelju, mora se izići izvan okvira kaznenog prava

\footnotetext{
${ }^{2}$ Kazneni zakon Federacije BiH, Službene novine FBiH, br. 36/03, 37/03, 21/04, 69/04, 18/05, 42/10, 42/11, 59/14 i 76/14 (dalje u tekstu: KZ FBiH).
} 
i potražiti odgovore u okviru filozofske antropologije. ${ }^{3}$ Stoga su u teoriji kaznenog prava nastale psihološke i normativne ${ }^{4}$ teorije o krivnji. O tim teorijama i danas postoje sporenja glede njihova prihvaćanja, ali ono što sa sigurnošću možemo zaključiti jeste činjenica da je kazneno zakonodavstvo Hrvatske, pa tako i $\mathrm{BiH}$, napustilo psihološke teorije ${ }^{5}$ i prihvatilo jednu od inačica psihološko-normativne teorije. Tako je i nastala definicija krivnje kao subjektivnog odnosa počinitelja prema djelu zbog kojeg mu se može uputiti prijekor. ${ }^{6}$ Time što vodi računa o krivnji suvremeno kazneno pravo odbija objektivnu odgovornost te zahtijeva da je počinitelj kriv za protupravno djelo; načelo krivnje. Otud načelo da nema kazne bez krivnje (nullum crimen nulla poena sine culpa $)^{7}$, čime se isključuje svaki oblik kažnjavanja koji bi se zasnivao na objektivnoj odgovornosti. Načelo krivnje ${ }^{8}$ ima u vidu pojam krivnje u materijalnom smislu, kao pravnopolitički postulat prema kojem krivnja opravdava državno kažnjavanje. Najjednostavnije rečeno, krivnja je legitimacija kazne, i to u dvostrukom smislu: kao pretpostavka da bi se uopće moglo kazniti, u kojem slučaju se govori o krivnji kao temelju kazne (Strafbegründungsschuld) i kao bitna pretpostavka za odmjeravanje kazne, u kojem slučaju se govori o krivnji kao mjeri kazne (Strafmaßschuld). ${ }^{9} \mathrm{~S}$ pomoću krivnje kao temelja kazne i krivnje kao mjere kazne načelo krivnje doživljava konkretnu primjenu. Kod krivnje kao temelja kazne radi se o skupu pretpostavki o kojima ovisi upućivanje prijekora za počinjenu protupravnu radnju. U hrvatskom kaznenom pravu to su ubrojivost, namjera ili nehaj, svijest o

\footnotetext{
${ }^{3}$ O slobodi i krivnji vidjeti: NOVOSELEC, P., BOJANIĆ, I., Opći dio kaznenog prava, četvrto izmijenjeno izdanje, Pravni fakultet Sveučilišta u Zagrebu, Zagreb, 2013., str. 215.

${ }^{4}$ Normativne teorije krivnje naglašavaju prijekor kao bitno obilježje krivnje. Povod su bili neki slučajevi krajnje nužde kod kojih se nije moglo opravdati isključenje protupravnosti, ali ni osuda počinitelja zbog postojanja posebnih okolnosti koje su vršile pritisak na njegovu motivaciju. Ibid, str. 218.

${ }^{5}$ Psihološke teorije nastale su u Njemačkoj krajem 19. stoljeća pod snažnim utjecajem pozitivističke filozofije koja je spoznaju htjela ograničiti na empirijski provjerljive činjenice. Tako se i krivnju htjelo svesti na gole psihičke procese kao subjektivne pretpostavke kažnjivosti. Otud i definicija krivnje kao subjektivnog odnosa počinitelja prema djelu. Krivnja se iscrpljuje u namjeri ili nehaju (oblici ili vrste krivnje), a ubrojivost je samo pretpostavka krivnje. Svijest o protupravnosti ili mogućnost takve svijesti ne smatra se elementom krivnje. Glavni prigovor psihološkim teorijama jest u tome što one ne mogu objasniti zašto je određeni psihički odnos krivnja i ne uzimaju u obzir da je krivnja neodvojiva od vrijednosne ili normativne ocjene. S pozicija čistog psihologizma ne može se, primjerice, odgovoriti na pitanje što je bit krivnje kod nesvjesnog nehaja jer kod tog oblika krivnje nema nikakvog počiniteljevog odnosa prema djelu; Ibid, str. 217.

${ }^{6} \mathrm{U}$ teoriji postoje shvaćanja prema kojima krivnja predstavlja dvostruki odnos. To je, prvo, psihički odnos počinitelja prema djelu, i drugo, to je odnos društva prema počinitelju zbog počinjenog djela; PETROVIĆ, B., JOVAŠEVIĆ, D., op.cit., str. 215., bilj. 83.; Isto tako FRANK, S., Teorija kaznenog prava, Školska knjiga, Zagreb, 1955., str. 138.

${ }^{7} \mathrm{O}$ načelu krivnje pročitati: BOJANIĆ, I., MRČELA, M., Koncepcija krivnje u novom Kaznenom zakonu, Hrvatski ljetopis za kazneno pravo i praksu, vol. 19, broj 2/2012, Zagreb, 2012., str. 389-407., dostupno na https://projektintegracija.pravo.hr/_download/repository/1_Bojanic.pdf (posjećeno 12. travnja 2018.).

${ }^{8} \mathrm{O}$ višestrukom značenju načela krivnje vidjeti: BAČCIĆ, F., Kazneno pravo - opći dio, peto prerađeno i prošireno izdanje, Informator, Zagreb, 1998., str. 198.

${ }^{9}$ ACHENBACH, H., Historische und dogmatische Grundlagen der strafrechtssystematischen Schuldlehre, Berlin, 1974., str. 4.
} 
protupravnosti ${ }^{10}$ i nepostojanje ispričavajućih razloga koji se u čl. 23. Kaznenog zakona Republike Hrvatske ${ }^{11}$ navode kao sastojci krivnje. Pri utvrđivanju krivnje kod fizičkih osoba krivnja ima dvobazični pojam. To znači da je krivnja kombinacija svijesti o djelu i svijesti o protupravnosti tog djela. Kod određenih kategorija počinitelja krivnja također uključuje svijest o osobnom svojstvu, bez koje svijesti nema ni konkretnog kaznenog djela. Kada govorimo o krivnji prema KZ-u FBiH, počinitelj je kriv ako je kazneno djelo počinio s namjerom, a ako ga je počinio iz nehaja, kriv je ako to zakon izričito propisuje. ${ }^{12}$

Kod krivnje kao mjere kazne riječ je o mjeri prijekora koja se upućuje počinitelju. Takva krivnja predstavlja kategoriju koja se može stupnjevati. Dok se kod krivnje kao temelja kazne uvijek radi samo o postojanju ili nepostojanju odgovarajućih sastojaka krivnje, za krivnju kao mjeru kazne bitna je mogućnost stupnjevanja; teža kazna pretpostavlja povišenu krivnju, a blaža kazna smanjenu krivnju. Oba se pojma odnose na prekorljivost počinjenog neprava, ali je razlika u tome što se kod krivnje kao temelja kazne postavlja pitanje hoće li se uputiti prijekor, a kod krivnje kao mjere kazne koja je težina prijekora koja se upućuje počinitelju. ${ }^{13}$ Takvo shvaćanje krivnje upućuje na zaključak da je ona, kad su u pitanju druge kaznenopravne sankcije, ipak u drugom planu. Ideja prijekora u pravilu je podređena specijalnoj prevenciji (uvjetna osuda, maloljetničke sankcije) ili je posve nebitna (sigurnosne mjere). Stoga definicija načela krivnje u čl. 4. KZ-a RH i čl. 4. KZ-a FBiH zaslužuje odobravanje. ${ }^{14}$

Iz zakonskih odredbi proizlazi da se krivnja može stupnjevati na namjeru i nehaj (oblici krivnje), kako je naveo prof. Bačić - dva jedina načina čovjekova ponašanja za koje zakon vezuje kaznu.

\footnotetext{
${ }^{10}$ Svijest o protupravnosti je počiniteljevo znanje da se svojom radnjom sukobljava s pravom ili da čini nešto pravno zabranjeno; NOVOSELEC, P., BOJANIĆ, I., op.cit., str. 259.; O pojmu svijesti o protupravnosti i njegovom mjestu u pojmu krivnje vidjeti: GROZDANIĆ, V., Svijest o protupravnosti kao element krivnje, Zbornik Pravnog fakulteta Sveučilišta u Zagrebu, br. 3-4/2002, Zagreb, 2002., str. 575-587.

${ }^{11}$ Kazneni zakon Republike Hrvatske, Narodne novine, br. 125/11, 144/12, 56/15, 61/15, 101/17 (dalje u tekstu: KZ RH).

${ }_{12}$ Čl. 35. KZ-a FBiH.

${ }^{13}$ NOVOSELEC, P., BOJANIĆ, I., op.cit., str. 212-214.

${ }^{14}$ Tako BOJANIĆ, I., MRČELA, M., op.cit., str. 395.; TURKOVIĆ, K., MARŠAVELSKI, A., Reforma sustava kazni u novom Kaznenom zakonu, Hrvatski ljetopis za kazneno pravo i praksu, vol. 19, broj 2/2012, Zagreb, 2012., str. 796-797. Nasuprot tome, u dijelu literature se ističe da je upravo definicija načela krivnje u čl. 4. Kaznenog zakona RH iz 1997. bila dosljedno provođenje tog načela; GROZDANIĆ, V., ŠKORIĆ, M., Uvod u kazneno pravo, opći dio, Organizator, Rijeka, 2009., str. 104. Za vraćanje na definiciju iz čl. 4. Kaznenog zakona RH iz 1997. i TRIPALO, D., BURIĆ, Z., Položaj neubrojivih počinitelja protupravnih djela u kontekstu novog hrvatskog kaznenog zakonodavstva, Hrvatski ljetopis za kazneno pravo i praksu, vol. 19, broj 2/2012, Zagreb, 2012., str. 508.; NOVOSELEC, P., BOJANIĆ, I., op.cit., bilj. 92.
} 


\subsection{Namjera}

Pitanje u čemu se sastoji bit namjere prepušteno je teoriji. Dok literatura obiluje napisima o svakom pojedinom obliku namjere, samoj se namjeri prostor posvećuje najčešće tek u širim teorijskim raspravama. Još je Radbruch, primjerice, tvrdio da se namjera može objasniti sa stajališta psihologije, ${ }^{15}$ što je u dijelu teorije ostalo prihvaćeno do danas. Prema danas uvriježenom mišljenju, namjera se najkraće može odrediti kao "ostvarenje plana" (Planverwirklichung); posljedica je ostvarena namjerno onda kada ona po objektivnoj ocjeni odgovara počiniteljevu planu. ${ }^{16}$

Kazneni zakon ne sadrži opću definiciju namjere (dolus), ${ }^{17}$ nego najprije propisuje da se kazneno djelo može počiniti s izravnom ili neizravnom namjerom, ${ }^{18}$ a zatim definira te dvije vrste namjere. Počinitelj postupa s izravnom namjerom (dolus directus) kad je svjestan obilježja kaznenog djela i hoće ili je siguran u njihovo ostvarenje, a s neizravnom namjerom (dolus eventualis) kad je svjestan da može ostvariti obilježja kaznenog djela pa na to pristaje.

Pojmom namjere bio je još u Kaznenom zakonu RH iz $1997 .{ }^{19}$ zamijenjen dotadašnji pojam umišljaja (njem. Vorsatz), vjerojatno zato što se umišljaj smatrao rusizmom (rus. namjera, nakana). Pojam namjere postojao je i u bivšem kaznenom pravu, ali u specifičnom značenju, kao naziv za subjektivno obilježje protupravnosti (njem. Absicht), kao što je npr. namjera prisvajanja kod krađe, pa novi pojam namjere treba razlikovati od takvog ranijeg što je otežano, jer se istodobno nije ustalio novi pojam koji bi odgovarao ranijem pojmu namjere (u obzir dolazi posebna namjera). S druge strane, neki autori smatraju upitnim može li novi pojam namjere obuhvatiti i dolus eventualis, jer namjera je po definiciji “ono što je tko odlučio učiniti, zamisao koja će ostvariti radnjom" 20 , pa neki smatraju neprikladno namjeru vezivati i uz pristajanje, u stvari je pojam neizravna namjera contradictio in adiecto. ${ }^{21}$ Osim toga, termin

\footnotetext{
${ }^{15}$ Prema: SINGER, M., Nehat - "kamen smutnje” u teoriji krivičnog prava, Naša zakonitost, vol. 18, br. 5-6/1964., Zagreb, 1964., str. 171.

${ }^{16}$ MARTINOVIĆ, I., Razgraničenje neizravne namjere i svjesnog nehaja, Hrvatski ljetopis za kazneno pravo i praksu, vol. 18, broj 1/2011, Zagreb, 2011., str. 53.

${ }^{17}$ Kritički o pojmu namjere: BAČIĆ, F., Marginalije uz novi Kazneni zakon, (opći dio), Hrvatski ljetopis za kazneno pravo i praksu, br. 2/1997, Vol. 4., Zagreb, 1997., str. 424.

${ }_{18}$ Čl. 37. KZ-a FBiH

${ }^{19}$ Kazneni zakon Republike Hrvatske, Narodne novine, br. 110/97, 129/00, 51/01, 111/03, 105/04, 84/05, 71/06, 110/07, 152/08 (dalje u tekstu: KZ RH/97).

${ }^{20}$ ANIĆ, V., Veliki rječnik hrvatskog jezika, Novi Liber, Zagreb, 2004.

${ }^{21}$ Contradictio in adiecto (lat.), unutarnja proturječnost; pridavanje atributa koji proturječi pojmu (drveno željezo, okrugli kvadrat), dostupno na https://www.hrleksikon.info/definicija/contradictio-in-adiecto.html (posjećeno 15. travnja 2018.).
} 
neizravna namjera upućuje i na latinski naziv dolus indirectus ${ }^{22}$ koji ima značenje sasvim različito od neizravne namjere.

U kaznenopravnoj literaturi ima pokušaja da se postavi opća definicija namjere, pa se npr. kaže da je namjera znanje i htijenje bića kaznenog djela. Ta definicija ipak više odgovara izravnoj nego neizravnoj namjeri, pogotovo ako se pođe od definicije KZ-a FBiH koji htijenje smatra samo obilježjem izravne namjere. Međutim, definicija namjere kao znanja i htijenja prihvatljiva je utoliko što ukazuje na to da obje vrste namjere sadrže intelektualnu (kognitivnu) i voljnu sastavnicu. ${ }^{23}$ Usprkos stalnim sporenjima o teorijskom položaju namjere, donedavno nije bilo upitno da namjera predstavlja svijest o (deskriptivnim i normativnim) obilježjima kaznenog djela te na taj način objedinjuje intelektualni (kognitivni) i voljni element. Međutim, u najnovijem doktrinarnom razvoju sve su glasniji i zahtjevi za odstupanjem od poimanja namjere kao čisto psihološkog odnosa. Pojedini autori zazivaju i odlazak psiholoških teorija namjere u ropotarnicu povijesti zajedno s psihološkim teorijama krivnje, te njihovu potpunu zamjenu normativnim teorijama namjere. Predvodnik tendencija normativizacije namjere znameniti je funkcionalist Jakobs, koji normativno shvaćanje namjere temelji na razumijevanju krivnje kao "manjkave lojalnosti počinitelja prema pravu” (mangelde Rechtstreue des Täters). Konkretno, namjera za Jakobsa predstavlja ravnodušnost prema činjenicama (Tatsachengleichgültigkeit), koja se sastoji u tome da počinitelj iz ukupnosti mogućih tokova izabire upravo onaj koji odgovara njegovim interesima. ${ }^{24}$

\subsubsection{Izravna namjera}

Dolus directus, kratko rečeno, svjesno je i voljno ostvarenje kaznenog djela. Počinitelj postupa s izravnom namjerom kad je svjestan obilježja kaznenog djela i hoće ili je siguran u njihovo ostvarenje. Iz te definicije se vidi da izravna namjera luči intelektualnu (kognitivnu) i

\footnotetext{
${ }^{22}$ Dolus indirectus (doslovce: neizravna namjera, ali ne u smislu u kome ga poznaju KZ RH i KZ FBiH) je pojam srednjovjekovnog kaznenog prava kojim se htjelo riješiti pitanje odgovornosti za težu posljedicu. To je u biti primjena teorije versari in re illicita prema kojoj se počinitelju zabranjenog djela uvijek uračunavaju sve posljedice koje proiziđu iz takvog djela. Na taj način se na tom području zapravo uvodio jedan oblik objektivne odgovornosti koji je u hrvatskom, te bosanskohercegovačkom kaznenom pravu napušten; NOVOSELEC, P., BOJANIĆ, I., op.cit., str. 246.

${ }^{23} \mathrm{Ibid}$, str. 238-239.

${ }^{24}$ Prema: GAEDE, K., Auf dem Weg zum potentiellen Vorsatz? Problematik und Berechtigung der zunehmenden Tendenzen zur normativen Relativierung des Vorsatzerfordernisses, Zeitschrift für die gesamte Strafrechtswissenschaft, Vol. 121., 2/2009., str. 243.; MARTINOVIĆ, I., op.cit., str. 54.
} 
voljnu sastavnicu namjere. Intelektualna sastavnica sastoji se u svijesti o obilježjima kaznenog djela. Ta svijest mora obuhvatiti sva obilježja kaznenog djela. ${ }^{25}$ Kod ubojstva počinitelj mora znati da ubija čovjeka, kod dvobračnosti mora znati da sklapa novi brak i da se već nalazi u braku, kod stavljanja u optjecaj krivotvorenog novca mora znati da je novac krivotvoren itd. Svijest mora obuhvatiti i kvalifikatorne okolnosti, npr. kod teškog ubojstva počinjenog na osobito okrutan način počinitelj mora znati da žrtva trpi intenzivne boli. ${ }^{26}$

Htijenje djela, kao obilježje izravne namjere, postoji kad je počinitelj htio nastupanje predviđene posljedice djela, odnosno kada je počinitelj poduzeo radnju počinjenja s ciljem da ostvari posljedicu na objektu napada. Počinitelj, također, pri ovom obliku namjere hoće nastupanje i one posljedice koja treba poslužiti kao sredstvo za ostvarenje glavne posljedice (npr. ubojstvo radi nasljeđa ubijenog, krivotvorenje isprave radi zaposlenja). Također, htijenje počinitelja obuhvaća i onu posljedicu koja nužno nastaje uz glavnu posljedicu na koju je usmjerena radnja, tzv. uzgredna posljedica. Najzad, počinitelj je htio posljedicu i onda kad je svjestan da će izvjesna daljnja posljedica nastupiti po ostvarenju njegove svrhe (npr. ubojstvo majke koja doji novorođenče). ${ }^{27}$ Počinitelj mora biti svjestan ne samo radnje i posljedice, nego i uzročne veze među njima. Pritom je dovoljno da njegova svijest obuhvati buduće zbivanje u bitnim crtama pa se ne traži ispravno predviđanje svih pojedinosti tog zbivanja koje su ionako najčešće nepredvidive. Stoga, nebitna odstupanja od zbiljskog kauzalnog toka od zamišljenog ne isključuju namjeru. ${ }^{28}$ Počiniteljeva svijest mora obuhvatiti, kako deskriptivna, tako i normativna obilježja kaznenog djela. Kod normativnih obilježja dovoljno je da počinitelj shvati značenje obilježja na laički način, a ne traži se i poznavanje pravnih pojmova jer bi inače za namjeru bila sposobna samo osoba s pravnim obrazovanjem. Dovoljna je tzv. " paralelna ocjena o laičkoj sferi". ${ }^{29}$ Svijest o djelu mora biti aktualna, tj. mora zbiljski postojati u vrijeme počinjenja djela, pa nije dovoljno da je počinitelj samo mogao imati takvu svijest (tzv. potencijalna svijest). Međutim, svijest ne mora biti jasna, tj. ne traži se da posjeduje visok stupanj zornosti, niti da bude artikulirana riječ, već je dovoljna i svijest u neizoštrenom obliku (prisvjesnost ili svijest na rubu). ${ }^{30}$ Voljna sastavnica izravne namjere sastoji se u tome da

\footnotetext{
${ }^{25}$ Primjerice kod kaznenog djela ubojstva počinitelj mora znati da ubija čovjeka, kod dvobračnosti mora znati da sklapa novi brak i da se već nalazi u braku i sl.

${ }^{26}$ Presuda Vrhovnog suda RH, I Kž-616/93.

${ }^{27}$ SRZENTIĆ, N., STAJIĆ, A., LAZAREVIĆ, Lj., Krivično pravo Socijalističke Federativne Republike Jugoslavije, opšti deo, Savremena administracija, Beograd, 1981., str. 240.

${ }^{28}$ Presuda Vrhovnog suda RH, I Kž-148/94.

${ }^{29}$ Pojam je pobliže razrađen u njemačkoj doktrini „Parallelwertung in der Laiensphare“; ROXIN, C., Strafrecht, Allgemeiner Teil, Band I Auflage, München, 2006., str. 486.

${ }^{30}$ Presuda Vrhovnog suda RH, I Kž-573/93.
} 
počinitelj hoće počinjenje djela. Po tome se izravna namjera razlikuje od neizravne kod koje se voljna sastavnica sastoji u pristajanju na kazneno djelo. Iako intelektualna i voljna sastavnica moraju postojati kod svake izravne namjere, ipak njihov međusobni odnos može biti različit. Zbog toga se razlikuju dvije vrste izravne namjere, i to izravna namjera prvog stupnja i izravna namjera drugog stupnja. ${ }^{31}$

\section{b) Izravna namjera prvog stupnja}

S izravnom namjerom prvog stupnja postupa počinitelj koji je svjestan obilježja kaznenog djela i hoće njihovo ostvarenje. Takva namjera postoji kad počinitelj ide za tim da ostvari obilježja kaznenog djela, kad mu je baš stalo do toga da počini kazneno djelo. To je ujedno i najčešći oblik izravne namjere u sudskoj praksi. Primjerice, u jednom slučaju počinitelj koji prati svoju bivšu suprugu i njezinog prijatelja, a onda ih ubija hicima iz pištolja za vrijeme spolnog odnosa u automobilu. Ovdje je u pitanju izravna namjera prvog stupnja jer je počinitelj išao za tim da usmrti žrtve. ${ }^{32}$ Kod izravne namjere prvog stupnja naglasak je na voljnoj sastavnici, iako je nazočna i intelektualna sastavnica (počinitelj je bio svjestan da pucanjem iz pištolja u dvije osobe može prouzročiti njihovu smrt). Baš zbog važnosti koju u ovom slučaju ima voljna sastavnica, dovoljno je da počinitelj koji djelo hoće posljedicu predvidi samo kao moguću, pa makar ta mogućnost bila i sasvim mala. U slučajevima kada je vjerojatnost nastupa posljedice mala, ali počinitelj računa upravo s takvom mogućnošću, sudovi ponekad smatraju da se radi samo o neizravnoj namjeri, npr. kad počinitelj baci nož na svoju suprugu htijući da se nož zabode u njezino tijelo ${ }^{33}$, ili kad počinitelj s 30-40 metara udaljenosti ispali rafal iz automatske puške na vozačicu koja ga po kišnom vremenu nije htjela povesti kao autostopera nego je nastavila vožnju i pritom je pogodi i usmrti. ${ }^{34} \mathrm{U}$ oba slučaja postojala je izravna namjera prvog stupnja na ubojstvo jer su počinitelji išli za time da usmrte žrtvu. Izravna namjera prvog stupnja postoji i kad počinitelj ne ide samo za tim da ostvari obilježje kaznenog djela nego istodobno ostvaruje i neke druge ciljeve. Čini kazneno djelo razbojničke krađe s izravnom namjerom prvog stupnja počinitelj koji upotrijebi silu protiv neke osobe ne samo zato da bi zadržao ukradenu stvar, nego i zato da ne bi bio uhvaćen. ${ }^{35}$

\footnotetext{
${ }^{31}$ NOVOSELEC, P., BOJANIĆ, I., op.cit., str. 239-241.

${ }^{32}$ Presuda Vrhovnog suda RH, I Kž-352/94.

${ }^{33}$ Presuda Vrhovnog suda RH, I Kž-512/91.

${ }^{34}$ Presuda Vrhovnog suda RH, I Kž-5/93.

${ }^{35}$ NOVOSELEC, P., BOJANIĆ, I., op.cit., str. 241-242.
} 
b) Izravna namjera drugog stupnja

S izravnom namjerom drugog stupnja postupa počinitelj kad je svjestan obilježja kaznenog djela i siguran je u njihovo ostvarenje. U tom slučaju počinitelju nije stalo do toga da počini kazneno djelo, ali znade da će ono biti počinjeno ako poduzme namjeravanu radnju. Zato se ta vrste namjera naziva i sigurno znanje. Sada je naglasak na intelektualnoj sastavnici, a voljna sastavnica je samo nužna posljedica jer tko poduzima radnju pouzdano znajući da će ostvariti obilježja kaznenog djela, taj u krajnjoj liniji i hoće počinjenje kaznenog djela. Takva namjera će postojati kad počinitelj hoće izvršiti atentat na neku osobu pa u zrakoplov kojim putuje ta osoba postavi bombu s tempiranim upaljačem tako da se ona aktivira dok zrakoplov bude u letu; u odnosu na osobu koja je cilj atentata postoji onda izravna namjera prvog stupnja, a u odnosu na ostale putnike i članove posade koji će također poginuti, izravna namjera drugog stupnja. Sigurno znanje postoji i kad je ostvarenje bića kaznenog djela prema iskustvu vjerojatno u visokom stupnju jer apsolutne sigurnosti u odnosu na buduće događaje ionako nema. Baci li atentator bombu na političara u automobilu, nije stopostotno sigurno da će poginuti i vozač automobila, ali je to vjerojatno u visokom stupnju; stoga će i u ovom slučaju postojati izravna namjera drugog stupnja u odnosu na ubojstvo vozača. ${ }^{36}$

\subsubsection{Neizravna namjera}

Neizravna namjera postoji kad je počinitelj svjestan da može ostvariti obilježja kaznenog djela pa na to pristaje. ${ }^{37}$ Intelektualna sastavnica određena je kao svijest o mogućnosti ostvarenja obilježja kaznenog djela, a voljna kao pristajanje na djelo. Svijest i pristajanje mogu se odnositi i na posljedicu, npr. smrt žrtve kod ubojstva, ali i na bilo koje drugo obilježje kaznenog djela objektivne naravi. Počinitelj kaznenog djela spolne zlouporabe djeteta mlađeg od petnaest godina postupa s neizravnom namjerom i kad izvrši spolni odnos s takvim djetetom ne znajući točno koliko je žrtva stara, ali dopuštajući da je mlađa od petnaest godina, takav počinitelj je svjestan mogućnosti da se radi o djetetu pa i uz tu pretpostavku pristaje na počinjenje djela. Svjesna i voljna sastavnica kaznenog djela u tom se slučaju ne određuju u

\footnotetext{
${ }^{36}$ Loc.cit.

${ }^{37}$ Eventualni dolus na specifičan način određuje Kazneni zakonik NR Kine kada definira kazneno djelo kao rezultat svjesnog znanja pri poduzimanju radnje kojom će se prouzročiti društveno opasna posljedica, pri čemu počinitelj gaji ravnodušnost (indiferentnost) prema prouzročenom događaju; PAGLE, C.D., Chinese Criminal Law, Peking, 1998.
} 
odnosu na posljedicu. To ujedno znači da je neizravna namjera moguća, kako kod materijalnih, tako i kod formalnih kaznenih djela. ${ }^{38}$ Neizravna namjera ne može postojati ako počinitelj uopće nema predodžbe o mogućnosti nastupanja posljedice (u takvom slučaju može se raditi o nesvjesnom nehaju). Eventualni dolus ne može postojati ni onda ako je počinitelj nastupanje posljedice predvidio kao sigurno, neizbježno, posve izvjesno (to je već područje direktnog dolusa). Osim na ostvarenje posljedice, sumnja se može odnositi i na svaku okolnost koja je obilježje zakonskog bića kaznenog djela. Taj dolus postoji kad počinitelj o bilo kojem obilježju zakonskog bića kaznenog djela nema sigurnu predodžbu, već ga samo kao mogućeg predviđa, kad kod njega postoji neizvjesnost, sumnja u vezi s postojanjem neke okolnosti koja je sastavni dio zakonskog bića kaznenog djela. Dakle, radi se o svijesti da može doći do ostvarenja zakonskog bića odnosnog djela. U odnosu na direktni dolus treba uočiti da i on može postojati i onda kad počinitelj predviđa da posljedica može nastupiti. I direktni i eventualni dolus mogu postojati kad počinitelj nastupanje posljedice predviđa samo kao moguće, ali neće se raditi o eventualnom dolusu ako je on siguran da će doći do ostvarenja zabranjene posljedice, u kojem slučaju nema više mjesta za izravnu namjeru. U cijelosti gledano, na intelektualnoj strani nema ničeg po čemu bi se bitno razlikovali direktni i eventualni dolus. Težište njihova razlikovanja je u voljnoj sastavnici. Voljna sastavnica kod neizravne namjere izražava počiniteljev stav prema mogućem nastupanju posljedice, i to kao pristajanje na djelo. Međutim, i tu se zapravo radi o htijenju djela u obliku pristajanja. Kod ove sastavnice neizravne namjere postavlja se nekoliko pitanja u odnosu na pristajanje. ${ }^{39}$ Voljnost u počinjenju djela u obliku pristajanja znači da počinitelj radi unatoč spoznaji evidentnog rizika nastupanja posljedice, koja spoznaja ne utječe da on odustane od djela; naprotiv, on prihvaća i nepovoljan ishod kao cijenu da postigne postavljeni cilj. Tako, počinitelj je u svoju odluku da djeluje kako bi došao do svog cilja uključio i to da nastupi posljedica iz bića djela; to znači drugim riječima, da je u svoju volju uključio i tu moguću zabranjenu posljedicu. Takav počiniteljev stav u odnosu na nastupanje posljedice formuliran kao pristajanje na nju je ekvivalentan onom htijenju posljedice koje imamo kod direktnog dolusa. ${ }^{40}$ Osobito ono dolazi do izražaja kod ciljnih delikata kakva su većina gospodarskih kaznenih djela, gdje počinitelj s posebnim svojstvom, unatoč tomu što je svjestan

\footnotetext{
${ }^{38}$ NOVOSELEC, P., BOJANIĆ, I., op.cit., str. 243.

${ }^{39}$ Kako shvatiti zakonsku formulu o pristajanju vidjeti: BAČIĆ, F., Kazneno pravo, op.cit., str. 239.; SCHULTZ, H., Einführung in den Allgemeinen Teil des Strafrechts, I., Bern, 1974., str. 140.; JESCHECK, H.H., Lehrbuch des Strafrechts, Allgemeiner Teil, Vierte Auflage, Berlin, 1996., str. 224.

${ }^{40}$ BAČIĆ, F., Kazneno pravo..., op.cit., str. 238.
} 
svoga osobnog svojstva i svjestan mogućnosti nastupanja posljedice, pristaje na činjenje djela radi cilja koji želi ostvariti.

\subsection{Neka posebna pitanja o namjeri}

Još je uvaženi profesor Bačić u svome udžbeniku iz 1998. godine istaknuo nekoliko pitanja o namjeri (dolusu) koja su i danas otvorena pitanja kaznenopravne znanosti. Prvo što bismo mogli reći da nije do kraja razriješeno jeste pitanje je li izravna namjera uvijek teži stupanj krivnje od neizravne. Osobito takvo pitanje nameće se zbog promjena koje su se implementirale u kazneno zakonodavstvo, kretanjem kriminaliteta i njegovim novim pojavnim oblicima. Neki autori smatraju da je izravna namjera teža s obzirom da se krivnja kao mjera kazne stupnjuje, tako se stupnjuju i njezini oblici. Međutim, kako je isticao i profesor Bačić, neizravna namjera ne znači uvijek blaži stupanj krivnje koji bi u svakom slučaju trebalo uzeti u obzir pri odmjeravanju kazne. Postoje slučajevi da počinitelj koji postupa s eventualnim dolusom postupa bezobzirnije i da je on društveno opasniji nego onaj koji postupa s direktnim dolusom. To se može zaključiti i iz analize jednog od najznačajnijih pitanja kaznenopravne znanosti koja se odnosi na razgraničenje neizravne namjere i svjesnog nehaja. Iz takvih analiza, koje su rezultirale i oblikovanjem različitih kaznenopravnih teorija, zaključuje se da neizravna namjera u svojoj voljnoj sastavnici obuhvaća neke elemente koji su sadržani u Frankovoj formuli. ${ }^{41}$ Prema prvoj formuli Reinharda Franka, počinitelj postupa s neizravnom namjerom ako se od činjenja ne bi uzdržao ni u slučaju da je štetan ishod, koji je pri ostvarenju radnje smatrao mogućim, predvidio kao siguran. ${ }^{42}$ Druga Frankova formula još je kraća: "Bilo kako bilo, svakako ću poduzeti radnju". ${ }^{43}$ Upravo zbog takvih elemenata neizravne namjere u njezinoj voljnoj sastavnici kod nekih kategorija počinitelja neizravna namjera može biti teži stupanj krivnje, osobito zbog njihovog posebnog svojstva i dužnosti koje su sadržane u samom pojmu takvih kategorija počinitelja kaznenih djela. Kad je riječ o intelektualnoj sastavnici, utvrđeno je da između izravne i neizravne namjere u tom pogledu nema bitnih razlika. Stoga bi

\footnotetext{
${ }^{41}$ MARTINOVIĆ, I., op.cit., str. 80-81., predlaže intelektualne sastavnice neizravne namjere po uzoru na austrijski KZ; dosadašnju svijest o mogućnosti počinjenja djela (ostvarenja njegovih obilježja) valja dopuniti i propisati da počinitelj treba biti svjestan „ozbiljne“ mogućnosti počinjenja djela.

${ }^{42}$ Parafrazirano prema: SINGER, M., Prilog problemu razgraničenja eventualnog umišljaja od svjesnog nehata, Naša zakonitost, 1-2/1960., str. 11; MARTINOVIĆ, I., op.cit., str. 63.

${ }^{43}$ ROXIN, C., op.cit., str. 461.; NOVOSELEC, P., Opći dio kaznenog prava, treće izmijenjeno izdanje, Pravni fakultet Sveučilišta u Zagrebu, Zagreb, 2009., str. 258.
} 
se kod nekih kategorija počinitelja voljna sastavnica neizravne namjere trebala uzeti u obzir pri odmjeravanju kazne za djelo za koje zakon propisuje izravnu namjeru kao uvjet kažnjivosti.

Međutim, općenito govoreći, kao pravilo se može uzeti da je u usporedbi s eventualnim dolusom, izravna namjera teži, da sadrži veći stupanj krivnje, što proizlazi u prvom redu iz razlike njihovih voljnih sastavnica. Kod pitanja koja se djela mogu počiniti s direktnim a koja s eventualnim dolusom, odgovor nalazimo u samom KZ-u. U zakonskim opisima djela zakon uopće ne spominje da se ona izvršavaju s direktnim ili eventualnim dolusom. To znači da se svako kazneno djelo može počiniti i s jednim i s drugim dolusom, osim ako su zakonski opisi tako konstruirani da isključuju eventualni dolus. Kod ciljnih delikata, npr. djelo krivotvorenja isprava isključen je eventualni dolus; kod drugog tipa ciljnih delikata, npr. ubojstvo iz koristoljublja nije isključena neizravna namjera. Kad zakon u nekim zakonskim opisima rabi riječi - zna, znajući, svjesno i sl., onda se tek tumačenjem svakog pojedinog opisa može zaključiti je li time eventualno isključena neizravna namjera, tj. radi li se o kaznenim djelima koja se mogu počiniti samo s izravnom namjerom. O izravnoj namjeri će se raditi ako se dođe do zaključka da zakon zahtijeva da počinitelj tražene okolnosti drži izvjesnim. ${ }^{44}$

Pitanje namjere osobito se pojavljuje kod nekih vrsta kaznenih djela s obzirom na krug mogućih počinitelja. Kako sam KZ izdvaja neke osobe kao osobe s posebnim svojstvom, tako bi kod tih osoba viši stupanj odgovornosti, a time i krivnje trebao postojati kao presumpcija, na što upućuju upravo tumačenja pojedinih zakonskih opisa kaznenih djela iz posebnog dijela KZ-a. Na prvi pogled čini se kao da bi se na taj način prešlo na neki vid objektivne odgovornosti, ali to nije tako. Osobe koje je KZ izdvojio kao one s posebnim svojstvom u svome bi pojmu, gledano sa stajališta kaznenog prava, trebale sadržavati viši stupanj odgovornosti koja predmnijeva i viši stupanj krivnje.

\section{Vrste kaznenih djela s obzirom na krug počinitelja}

Prema krugu mogućih počinitelja, razlikuju se opća, posebna i vlastoručna kaznena djela. Opća kaznena djela (delicta communia) su kaznena djela koja može počiniti svatko. Lako ih se može prepoznati po tome što njihov zakonski opis počinje odnosnom zamjenicom "tko". S druge strane, posebna kaznena djela (delicta propria) mogu počiniti samo osobe s određenim

\footnotetext{
${ }^{44}$ BAČIĆ, F., Kazneno pravo...op.cit., str. 240. - 241.
} 
svojstvom koje je posebno istaknuto u zakonskom opisu. Kod njih je, dakle, krug mogućih počinitelja sužen. Najčešće je riječ o kaznenim djelima koja mogu počiniti samo "službene osobe", "odgovorne osobe" ili "vojne osobe", ali svojstvo počinitelja može biti definirano i drukčije, npr. kao "doktor medicine” kod nesavjesnog liječenja (čl. 229. KZ-a FBiH) ili kao "građanin Federacije BiH" kod niza kaznenih djela protiv ustavnog poretka Federacije (glava XV. KZ-a FBiH). Nadalje, razlikuju se prava i neprava posebna kaznena djela. Kod pravih posebnih kaznenih djela svojstvo počinitelja utječe na samo postojanje kaznenog djela, dok neprava posebna kaznena djela može počiniti svatko, ali je posebno svojstvo počinitelja kvalifikatorna okolnost, npr. kod povrede ravnopravnosti u vršenju gospodarske djelatnosti (čl. 241. st. 1. KZ-a FBiH ) može počiniti svatko, ali djelo postaje kvalificirano (čl. 241. st. 2. KZa FBiH) ako ga počini "službena ili odgovorna osoba osoba zlouporabom svog službenog položaja”. Krug mogućih počinitelja sužen je i kod vlastoručnih kaznenih djela. To su kaznena djela koja počinitelj mora sam izvršiti, bilo da je potrebno tjelesno sudjelovanje u počinjenju, bilo da je na drugi način potrebno njegovo osobno sudjelovanje u radnji počinjenja, kao npr. kod dvobračnosti (čl. 214. KZ-a FBiH) ili davanju lažnog iskaza (čl. 348. KZ-a FBiH).

Također, osobe koje kod pravih delicta propria nemaju traženo svojstvo, odnosno koje kod vlastoručnih kaznenih djela osobito ne izvršavaju radnju, ne mogu biti počinitelji (ni neposredni ni posredni) niti supočinitelji, ali mogu biti poticatelji ili pomagači. ${ }^{45} \mathrm{Kod}$ nepravih delicta propria osobe koje imaju i one koje nemaju svojstvo mogu biti supočinitelji, ali će se osoba koja nema svojstvo kazniti za temeljni, a osoba koja ima svojstvo za kvalificirani oblik; npr. zatvore li protupravno drugoga, običan građanin i policijski djelatnik bit će supočinitelji, ali će prvi odgovarati za temeljni (čl. 136. st. 1. KZ-a RH), a drugi za kvalificirani oblik protupravnog oduzimanja slobode (čl. 136. st. 3. KZ-a RH). ${ }^{46}$

Iz samog zakona, iz zakonskih opisa djela, ne vidi se neposredno koja su djela vlastoručna kaznena djela. Ni u teoriji ne postoji uvijek suglasnost koja su djela iz posebnog dijela KZ-a takve prirode. Tek tumačenjem zakonskih opisa djela može se doći do odgovora na to pitanje. Polazi se od toga je li za sam karakter neprava odlučujuće tko će biti počinitelj, pripada li nepravu kao odlučujuće svojstvo baš osobno poduzimanje nedopuštenog djela. Drugim riječima, ima kaznenih djela gdje je njihovo izvršenje tako individualno povezano s ličnosti

\footnotetext{
${ }^{45} \mathrm{O}$ sudjelovanju više osoba u počinjenju gospodarskog kaznenog djela vidjeti: NOVOSELEC, P., Aktualni problemi hrvatskog gospodarskog kaznenog prava, Hrvatski ljetopis za kazneno pravo i praksu, vol. 14, broj 2/2007, Zagreb, 2007., str. 379-385.

${ }^{46}$ NOVOSELEC, P., BOJANIĆ, I., op.cit., str. 136-137.
} 
počinitelja da ga on sam mora vlastoručno poduzeti; negdje se opet, kod nekih djela, sama radnja ne može fizički odvojiti od određenog počinitelja. Ako se to zaključi, onda se radi o vlastoručnom kaznenom djelu. ${ }^{47}$

Na temelju navedene podjele kaznenih djela uočavamo da su, između ostalih, odgovorne osobe kao osobe s posebnim svojstvom i uvjet klasificiranja kaznenih djela kao delicta propria. No, ono što uočavamo unutar posebnog dijela KZ-a FBiH glede ovih posebnih kaznenih djela jeste to da je veliki broj delicta propria propisan kao neprava posebna kaznena djela, ali se posebno svojstvo počinitelja ne uzima kao kvalifikatorna okolnost. Na to upućuju zakonski opisi pojedinih kaznenih djela koji predviđaju istu kaznu za "svakog" počinitelja i počinitelja s posebnim svojstvom - odgovornu osobu. ${ }^{48}$ Dakle, posebno svojstvo odgovorne osobe, osim kao uvjet klasificiranja djela, uzima se i kao kvalifikatorna okolnost kod delicta communia. To upućuje na zaključak da je posebno svojstvo počinitelja okolnost koja u svom jedinstvu obuhvaća nekoliko važnih elemenata. Svi ti element važni su za utvrđivanje kaznene odgovornosti odgovorne osobe, jer bez njih neće postojati ni odnosno kazneno djelo, a niti će se moći utvrditi krivnja odgovorne osobe kao osobe s posebnim svojstvom.

\subsection{Gospodarska kaznena djela - delicta propria}

U suvremenom kaznenom pravu nastala je i podjela kaznenih djela na gospodarska kaznena djela ${ }^{49}$, jednako kao i oblik kriminaliteta - gospodarski kriminalitet ${ }^{50}$, ili još dalje grana kaznenog prava - gospodarsko kazneno pravo. Premda u teoriji kaznenog prava još uvijek ne postoji suglasnost o implementaciji ove grane prava u kazneno materijalno pravo, točnije njegov opći dio, ipak posebni dijelovi kaznenih zakona upućuju na neprijeporno postojanje pravih gospodarskih delikata. Na ovu granu prava imaju se primijeniti instituti općeg dijela kaznenih zakona, no ipak postoje neke specifičnosti kod ovih kaznenih djela, u prvom redu

\footnotetext{
${ }^{47}$ BAČIĆ, F., Kazneno pravo..., cit. u bilj. 21., str. 311-312.

${ }^{48}$ Pojam 'odgovoran' znači onaj koji savjesno s odgovornošću obavlja dužnosti, ili koji ima dužnost obaviti neki posao, zadatak i za rezultate toga preuzima odgovornost. Hrvatski jezični portal, dostupno na http://hjp.znanje.hr (27. travnja 2018.).

${ }^{49} \mathrm{O}$ nepostojanju suglasnosti da se kaznena djela dijele i na gospodarska vidjeti u: NOVOSELEC, P., Aktualni problemi hrvatskog. op.cit., str. 394.

${ }^{50} \mathrm{O}$ pojmu gospodarskog kriminaliteta vidjeti različite definicije u BIJELIĆ, S., ĆUROVAC, S., Pojavni oblici privrednog kriminala i način njihovog dokazivanja, edukativni modul, Sarajevo, 2016., str. 9.
} 
kruga počinitelja. Većina gospodarskih kaznenih djela ${ }^{51}$ su posebna kaznena djela (a neka i vlastoručna) s obzirom na prirodu samih djela, ali kazneni zakoni nisu suglasni glede određenja vrste kaznenog djela, a samim time i kruga počinitelja gospodarskih kaznenih djela. Tako primjerice u glavi XXII. KZ-a FBiH kod kaznenih djela protiv gospodarstva, poslovanja i sigurnosti platnog prometa uočava se da su većina kaznenih djela u njihovim prvim stavcima zakonskih opisa označena kao neprava posebna kaznena djela, a posebno svojstvo počinitelja propisuje kao kvalifikatornu okolnost. Tek nekoliko kaznenih djela označena su kao delicta propria, a po svojoj prirodi ne razlikuju se od navedenih djela. Imajući u vidu da je kazneno pravo u svojoj biti restriktivno i da bi se izbjegle određene nesuglasice, gospodarska kaznena djela trebala bi biti restriktivno i određena, odnosno trebalo bi nedvosmisleno propisati krug mogućih počinitelja s obzirom na prirodu djela. ${ }^{52}$ To također povlači obvezu zakonopisca da $u$ općem dijelu zakona definira pojam osobe s posebnim svojstvom na način da se obuhvate osobe koje se mogu pojaviti kao počinitelji gospodarskih kaznenih djela prema njihovoj prirodi i zakonskim opisima, ali i drugih djela iz posebnog dijela KZ-a, primjerice kaznenih djela protiv zdravlja ljudi. Na taj način doprinijelo bi se lakšem otkrivanju navedenih kaznenih djela te pronalaženju njihovih počinitelja.

\subsection{Odgovorna osoba kao počinitelj delicta propria}

Jedan od ključnih pojmova u analizi kaznene odgovornosti za delicta propria je pojam odgovorne osobe. Ovaj pojam u kazneno pravo implementiran je upravo nastankom gospodarskog kriminaliteta, odnosno preuzimanjem određenih inkriminacija iz austrijskog i njemačkog kaznenog zakonodavstva. U teoriji kaznenog prava postoje različita shvaćanja o pojmu odgovorne osobe. Tako neki smatraju da je odgovorna osoba "mozak" pravne osobe te da je za kaznena djela pravnih osoba dovoljno nužno utvrditi odgovornu osobu. Drugi smatraju da je pojam odgovorne osobe suvišan te da ga treba potpuno izbaciti iz kaznenog zakonodavstva, a da će se krug mogućih počinitelja odrediti u opisu svakog kaznenog djela

\footnotetext{
${ }^{51}$ Podjele gospodarskih kaznenih djela vidjeti u: ORLOVIĆ, A., Gospodarski kriminalitet u Kaznenom zakonu modus operandi (ekonomski aspekt), Policijska sigurnost, godina 18., broj 1, Zagreb, 2009., str. 1-25.; KALEB, Z., Gospodarska kaznena djela iz područja trgovačkih društava i vrijednosnih papira, Zgombić \& partnerinakladništvo i informatika d.o.o., Zagreb, 2006., str. 3.

${ }^{52}$ Vidjeti primjerice raniju regulativu za kazneno djelo prouzročenja stečaja u: RAJIĆ, Z., TOMIĆ, M., MILJKO, Z., Komentar Kaznenog zakona Federacije Bosne i Hercegovine (Posebni dio), OSCE, Mostar, 2000., str. 381 383.
} 
posebno. Na to upućuju i moderni kazneni zakonici koji gospodarska kaznena djela tretiraju kao delicta communia, iako po zakonskim opisima djela ona to nisu. ${ }^{53}$ Međutim, implementacijom pravnih osoba kao počinitelja kaznenih djela u kaznenopravne sustave nesporno je potrebno utvrditi odgovornu osobu kako bi se (prema akcesornom modelu) mogla utvrditi krivnja pravne osobe. Odgovorna osoba nositelj je aktivnosti, poslovanja i odgovornosti kako individualne, tako i odgovornosti pravnih osoba. Stoga je od iznimne važnosti dogmatički tumačiti definiciju odgovorne osobe unutar kaznenog zakonodavstva. Tu primarno treba imati na umu da pojam odgovorne osobe mora obuhvatiti one kategorije koje se sa stajališta kaznenog prava mogu pojaviti kao počinitelji određenih kaznenih djela. Odgovorna osoba zbog dužnosti koje ima smatra se osobom s posebnim svojstvom, te se pojavljuje kao počinitelj niza posebnih kaznenih djela kakva su gospodarska kaznena djela. U bosanskohercegovačkom kaznenom zakonodavstvu odgovorna osoba definirana je kao osoba u gospodarskom društvu ili u drugoj pravnoj osobi kojoj je s obzirom na njenu dužnost ili na osnovi posebne ovlasti povjeren određeni krug poslova koji se odnose na primjenu zakona ili propisa donesenih na osnovi zakona, ili općeg akta gospodarskog društva ili druge pravne osobe u upravljanju i rukovanju imovinom, ili se odnose na rukovođenje proizvodnjom ili nekom drugom gospodarskom djelatnošću ili na nadzor nad njima. ${ }^{54}$ Analizom pojma odgovorne osobe i poredbenopravnih rješenja, napose preuzetih međunarodnih obveza i implementacije međunarodnih konvencija, pojam odgovorne osobe u $\mathrm{BiH}$ ne korespondira navedenim rješenjima. Stoga je primarno potrebno ovaj pojam uskladiti s čl. 18. Kaznenopravne konvencije o korupciji ${ }^{55}$ koji navodi da je odgovorna osoba ona fizička osoba koja ima vodeću ulogu u pravnoj osobi, koja je zastupa, donosi ključne odluke za tu pravnu osobu te vrši nadzor nad radom te pravne osobe. Poredbenopravna iskustva proširuju ovaj pojam i na osobe kojima je povjereno obavljanje

\footnotetext{
${ }^{53}$ Tako NOVOSELEC, P., Aktualni problemi hrvatskog..., op.cit., str. 374-375.

${ }^{54}$ Čl. 2. st. 6. KZ-a FBiH.

${ }^{55}$ C̆l. 18. Kaznenopravne konvencije o korupciji pod nazivom 'Odgovornost pravne osobe' propisuje: „1. Svaka zemlja potpisnica donijet će one pravne i druge mjere koje bi mogle poslužiti kao jamstvo da se pravne osobe mogu smatrati odgovornima za kaznene prekršaje aktivnog podmićivanja, trgovanja utjecajem i pranja novca, utvrđenima sukladno ovoj Konvenciji, a koje je u njihovu korist počinila bilo koja fizička osoba, djelujući zasebno ili kao dio pravne osobe, koja ima vodeću ulogu unutar te pravne osobe, i na temelju:

- prava na zastupanje dotične pravne osobe ili

- ovlasti za donošenje odluka u ime dotične pravne osobe, ili

- ovlasti za obavljanje nadzora unutar dotične pravne osobe te

- njena uključivanja kao suučesnika ili poticatelja glede gore spomenutih prekršaja.

2. Osim u slučajevima već spomenutim u stavku 1., svaka zemlja potpisnica poduzet će nužne mjere u svezi s jamstvom da pravne osobe mogu snositi odgovornost u slučaju kad je zbog nedostatka nadzora koji je morala obavljati fizička osoba spomenuta u stavku 1. došlo do kaznenog prekršaja navedenog u istom stavku u korist te pravne osobe, koji je počinila fizička osoba pod nadležnošću te pravne osobe.

3. Odgovornost pravne osobe prema stavcima 1. i 2. ne isključuje pokretanje kaznenog postupka protiv fizičke osobe koja je bila počinitelj, poticatelj ili suučesnik kaznenih prekršaja navedenih u stavku 1.; Zakon o potvrđivanju Kaznenopravne konvencije o korupciji (Narodne novine, Međunarodni ugovori br. 11/00)
} 
navedenih poslova ${ }^{56}$, pa se pri utvrđivanju odgovorne osobe kao počinitelja kaznenog djela ne može pozivati samo na formalnopravni element, nego se mora uzeti u obzir i materijalni element. ${ }^{57}$ Razlog proširenja osoba koje se smatraju odgovornima je upravo težina djela koje odgovorne osobe čine, te u nedostatku njezinoga svojstva ostavljaju se nesankcionirani pravi počinitelji kaznenih djela. Stoga je cilj kaznenog prava restriktivnim ${ }^{58}$ definiranjem i tumačenjem pojedinih pojmova unutar kaznenog zakonodavstva olakšati put pronalaska i otkrivanja kaznenih djela i njihovih počinitelja. U tom pogledu odgovorna osoba kao osoba s posebnim svojstvom u svom jedinstvu mora obuhvatiti primarno osobe koje imaju vodeću ulogu u nekom gospodarskom društvu, koje zastupaju to društvo, donose ključne odluke za društvo te vrše nadzor nad radom tog društva, kao i osobe kojima je povjereno obavljanje navedenih poslova. To ne znači da se osoba koja je povjerila poslove osobi koja je stvarni počinitelj kaznenog djela neće smatrati odgovornom, barem kao sudionik u počinjenju djela. $\mathrm{S}$ druge strane, neće se radnja svakog zaposlenika koji obavlja samo tehničku funkciju moći smatrati radnjom odgovorne osobe. Na taj način olakšat će se put pronalaska, otkrivanja te utvrđivanja kaznene odgovornosti odgovorne osobe. Dogmatičkim pristupom pojmu odgovorne osobe omogućava se i lakše utvrđivanje njezine kaznene odgovornosti, odnosno pojedinih sastojaka krivnje.

\footnotetext{
${ }^{56}$ Vidjeti o distinkciji vođenja poslova i povjeravanju obavljanja određenih poslova u: BARBIĆ, J., Osobe koje vode poslove kao odgovorne osobe i određenje predstavnika pravne osobe po Zakonu o odgovornosti pravnih osoba za kaznena djela, Hrvatski ljetopis za kazneno pravo i praksu, vol. 10, broj 2/2003, Zagreb, 2003., str. 779842 .

${ }^{57}$ DERENČINOVIĆ, D., Sedam pitanja u vezi s utvrđivanjem pojma „odgovorne osobe“ u hrvatskom kaznenom pravu i sudskoj praksi, Pravo i porezi br. 9, Zagreb, 2003., str. 4.

${ }^{58} \mathrm{Za}$ uži pojam odgovorne osobe zalagao se i prof. Zlatarić: "Svatko tko je zaposlen u određenoj organizaciji (gospodarskom subjektu) ima izvjesna zaduženja i odgovara za svoj posao. Ipak samim time ne može se još smatrati odgovornom osobom. Mora se prije svega raditi o takvom zaduženju koje predstavlja poslovanje u gospodarskom subjektu, a to znači da odatle ispada čisto tehnički i manuelni posao. Ali, ni svako poslovanje ne dovodi još do svojstva odgovorne osobe. Za to svojstvo potrebna je izvjesna samostalnost u radu i izvjesno pravo samostalnog odlučivanja. Rukovodeća ili nadzorna funkcija svakako će zasnovati svojstvo odgovorne osobe, ali ona nije za to neophodno potrebna. Tako npr. samostalni poslovođa neke prodavaonice, koji je i jedini zaposlen u toj radnji, predstavljat će već odgovornu osobu. Isto tako npr. samostalni blagajnik neke privredne organizacije, pa samostalni knjigovođa ili samostalni skladištar, mada ne vrše neku rukovodeću ili nadzornu funkciju predstavljaju odgovorne osobe. S druge strane, prodavač u nekoj prodavaonici, ako u njoj postoji i poslovođa, ne može se smatrati još odgovornom osobom, mada dolazi u neposredni kontakt s građanima i u ime poduzeća sklapa s njima pravne poslove." ZLATARIĆ, B., Krivični zakonik u praktičnoj primjeni, II. svezak, Posebni dio, Narodne novine, 1958., str. 263.; O restriktivnom definiranju pojma odgovorne osobe za gospodarska kaznena djela i: PRIMORAC, D., BUHOVAC, M., Criminal justice aspects of causing false bankruptcy, Book of proceedings 16th International Scientific Conference on Economic and Social Development - "Legal Challenges of Modern World", Split, 2016., str. 2-11.
} 


\section{Implementacija izravne namjere u kaznenu odgovornost odgovorne osobe kod gospodarskih kaznenih djela}

Kao što ne postoji suglasnost u određenju kruga mogućih počinitelja kod gospodarskih kaznenih djela, ${ }^{59}$ tako su i različito definirani uvjeti kažnjivosti tih počinitelja. Kod nekih gospodarskih kaznenih djela uočava se da su ta djela regulirana kao neprava posebna kaznena djela, a za kažnjivost uvjetuju izravnu namjeru počinitelja. Takvo je djelo npr. prouzročenje stečaja (čl. 243. KZ-a FBiH). Ako sadržaj izravne namjere povežemo s posebnim svojstvom odgovorne osobe koja vodi poslove pravne osobe, zastupa tu pravnu osobu, te vrši nadzor nad njezinim radom, teško je zamisliti situaciju da takva osoba nije imala svijest o vlastitom svojstvu, svijest o protupravnosti djela ili svijest o biću djela. Odgovorne, službene, vojne i druge osobe s posebnim svojstvom su pojedinci ili kolektivna tijela koja su najbolje upućena u djelovanje i poslovanje određenog društva. Analizirajući zakonske opise pojedinih gospodarskih kaznenih djela, konkretno iz glave XXII. KZ-a FBiH, prijeporno bi bilo uopće utvrđivati je li neka osoba s takvim svojstvom znala za svoje osobno svojstvo ${ }^{60}$, te za protupravnost radnji koje samo ona i može poduzeti s obzirom na njezino posebno svojstvo, a osobito zbog cilja poduzimanja nedopuštenih aktivnosti. Dakle, znanje odgovorne osobe o osobnom svojstvu te svijest o protupravnosti djela trebale bi se kod ovih djela presumirati. Ovakvo postavljanje uvjeta kažnjivosti opravdava se i time što u nedostatku izravne namjere neće postojati ni odnosno kazneno djelo. Težište bi trebalo biti na cilju počinjenja djela, a za kažnjavanje bi bila dovoljna i neizravna namjera, tim više što bi voljna sastavnica neizravne namjere $\mathrm{u}$ obliku pristajanja kod ovih kategorija počinitelja bila otegotna okolnost pri odmjeravanju kazne. Cilj počinjenja većine gospodarskih kaznenih djela je stjecanje protupravne imovinske koristi, pa bi dokazivanje znanja odgovorne osobe o osobnom svojstvu te znanja o protupravnosti djela relativiziralo mogućnost utvrđivanja njegove krivnje. To ni na koji način ne znači stigmatizirati odgovornu osobu i proglasiti je odmah krivom, ali njezina svijest o navedenim okolnostima mora biti izvjesna da bi uopće mogla počiniti djelo.

\footnotetext{
${ }^{59}$ To uočava i profesor Novoselec koji navodi kako zakon glede uporabe pojma odgovorne osobe nije dosljedan jer kod nekih gospodarskih kaznenih djela počinitelj jest određen kao odgovorna osoba, ali ne i u nizu drugih, npr. zlouporabe stečaja. Vidjeti: NOVOSELEC, P., Uvod u gospodarsko kazneno pravo, Pravni fakultet Sveučilišta u Zagrebu, Zagreb, 2009., str. 11.

${ }^{60}$ Tako prof. Tomić navodi da je za utvrđivanje kaznene odgovornosti većine kaznenih djela iz glave XXII. KZ-a FBiH potrebno utvrditi svijest o osobnom svojstvu, tj. da je počinitelj svjestan da je odgovorna ili službena osoba. TOMIĆ, Z., Krivično pravo II, posebni dio, Pravni fakultet Univerziteta u Sarajevu, Sarajevo, 2007., str. 169. i dalje
} 
Primjerice, kod kaznenog djela lažnog stečaja (čl. 243. KZ-a FBiH), prema zakonskom opisu djela, “djelo čini onaj tko znajući za svoju prezaduženost...", dakle to je nitko drugi nego stečajni dužnik koji ciljano čini protupravne radnje znajući za svoju insolventnost. Osim što je ovo djelo delicta propria, ono ima obilježja i vlastoručnog kaznenog djela. Ako bismo kod ovakvog kaznenog djela dopustili utvrđivanje izravne namjere odgovorne osobe koja neprijeporno postoji, jer drukčije se djelo ne može ni počiniti, to bi vodilo do pravne nesigurnosti što nikako nije cilj uvođenja takvih inkriminacija. Dakle, znanje odgovorne osobe za delicta propria se treba presumirati, a njezina voljna sastavnica u činjenju nedopuštenih radnji sastojala bi se u pristajanju. Pristajanje nije ništa drugo nego oblik htijenja, ali u ovim slučajevima ono ima kvalifikatorne elemente. Na prvi pogled izgleda da se radi o kontradiktornom rješenju koje omogućava da se počinitelj kazni težom kaznom za blaži stupanj krivnje. Međutim, kako je ranije kazano, neizravna namjera ne mora uvijek biti blaži stupanj krivnje od izravne. ${ }^{61} \mathrm{Na}$ taj način približili bismo utvrđivanje krivnje kod odgovornih osoba za delicta propria objektivnim uvjetima kažnjivosti ${ }^{62}$ kao materijalnim pretpostavkama koje ne pripadaju ni protupravnosti ni krivnji. S obzirom na podjelu na pravi i nepravi objektivni uvjet kažnjivosti, ${ }^{63}$ za delicta propria kakva su gospodarska kaznena djela došao bi eventualno u obzir pravi objektivni uvjet kažnjivosti kojem je glavna uloga da suzi kažnjivost. Radi se o slučajevima u kojima neko ponašanje samo po sebi, tj. i bez objektivnog uvjeta kažnjivosti, zaslužuje da bude kažnjeno u granicama kazne propisane za to kazneno djelo. Tako profesor Novoselec i Bojanić navode kao primjer kazneno djelo prouzročenja stečaja, navodeći kako se kod njega pravi objektivni uvjet kažnjivosti ogleda u tome da su radnje koje čine ovo kazneno djelo toliko opasne da već po sebi zaslužuju kažnjavanje. ${ }^{64}$ Samim time, dokazivanje izravne namjere odgovornoj osobi za ovakva djela otežava utvrđivanje njezine kaznene odgovornosti. S obzirom da se radi o dosta oštroj reakciji na kažnjivo ponašanje odgovornih osoba, ovakvo postavljanje uvjeta kažnjavanja tek je idejno rješenje. U svakom slučaju, s obzirom na izloženo o neizravnoj namjeri, možemo reći da bi utvrđivanje kaznene odgovornosti odgovornoj osobi s obzirom na neizravnu namjeru bila jedna od iznimnih situacija kada odgovorna osoba odgovara za općenito blaži stupanj krivnje kao teži, upravo zato što je s obzirom na svoje svojstvo mogla odustati od počinjenja djela, ali je pod svaku cijenu to pristala učiniti.

\footnotetext{
${ }^{61}$ Vidjeti supra, str. 11.

${ }^{62}$ O tome: ATANACKOVIĆ, D., Objektivni uslovi inkriminacije u jugoslovenskom krivičnom zakonodavstvu, Zbornik Pravnog fakulteta u Mostaru, II-III, Mostar, 1980.-1981.

${ }^{63}$ JESCHECK, H.H., WEIGEND, T., Lehrbuch des Strafrechts, Allgemeneiner Teil, 5 Auflage, Berlin, 1996., str. 556.; TRIFFTERER, O., Österreichisches Strafrecht Allgemeiner Teil, 2 Auflage, Wien, 1994., str. 194.

${ }^{64}$ NOVOSELEC, P., BOJANIĆ, I., op.cit., str. 277.
} 


\section{Zaključna razmatranja}

Kazneno materijalno pravo, premda se zasniva na postavljenim kaznenopravnim postulatima i institutima, podvrgava se određenim promjenama ili bolje rečeno iznimkama, što je rezultat dinamičnih izmjena kaznenih zakona osobito u njegovom posebnom dijelu. Posebni dijelovi kaznenih zakona moraju se uskladiti s materijalnopravnim postulatima pa je ovim radom ukazano na nekoliko problema koji se pojavljuju kod utvrđivanja krivnje odgovornih osoba za delicta propria kakva su gospodarska kaznena djela. Da bismo mogli ukazati na navedene probleme, radom su analizirani pojedini instituti kaznene odgovornosti te je prikazana njihova međusobna povezanost. Na taj način dani su de lege ferenda prijedlozi u svrhu ostvarivanja kažnjavanja počinitelja i u svrhu izricanja kaznenopravnih sankcija. Primarno su utvrđeni materijalnopravni aspekti namjere (dolusa) kao sastojka krivnje kako bismo oba stupnja krivnje mogli implementirati na određene počinitelje. Ti određeni počinitelji javljaju se kao počinitelji određenih kaznenih djela, na osnovi čega i postoji podjela kaznenih djela s obzirom na krug počinitelja. To su, osim vlastoručnih, i delicta communia, delicta propria djela koja mogu počiniti samo osobe s posebnim svojstvom, pa je radom analiziran pojam odgovorne osobe kao osobe s posebnim svojstvom. Odgovorne osobe počinitelji su niza kaznenih djela te je za njihovu kažnjivost, osim dogmatički utvrđene definicije pojma odgovorne osobe u KZ-u FBiH, od iznimnog značaja olakšati put utvrđivanja kaznene odgovornosti. Upravo za neka delicta propria kakva su gospodarska kaznena djela, gdje se kao počinitelji javljaju odgovorne osobe, zakon propisuje kao uvjet kažnjivosti izravnu namjeru odgovorne osobe. Takvim reguliranjem relativizira se mogućnost utvrđivanja kaznene odgovornosti ili pak krivnje odgovorne osobe, što dovodi do pravne nesigurnosti i opasnosti od nesankcioniranja za teška kaznena djela iz posebnog dijela KZ-a FBiH. Stoga bi se prema prijedlogu iz ovog rada izravna namjera kod odgovornih osoba kao počinitelja kaznenih djela trebala presumirati kao što se ubrojivost presumira kod "svakog" počinitelja, a za kažnjavanje bi bila dovoljna i neizravna namjera. Na taj način kaznila bi se odgovorna osoba za radnje koje svjesno čini i u situacijama kada samo pristaje na počinjenje djela, jer i pristajanje na djelo je jedan oblik htijenja koji se u ovom slučaju uzima kao kvalifikatorna okolnost pri odmjeravanju kazne. To stoga što znanje i svijest o osobnom svojstvu i protupravnosti djela kod odgovornih osoba neprijeporno trebaju postojati kao rezultat njezina posebnog svojstva. 
PRIMORAC, D., BUHOVAC, M., Izravna namjera kao uvjet kažnjivosti odgovornih osoba za delicta propria Zbornik radova Pravnog fakulteta Sveučilišta u Mostaru br. XXVI., 2018., str. 37. - 58.

\section{CRIMINAL INTENT AS CONDITION OF LIABILITY OF PERSONS RESPONSIBLE FOR DELICTA PROPRIA}

Summary: The paper deals with the issue of determining the criminal liability of the responsible persons, who appear to be perpetrators of a series criminal offenses from a special part of the Criminal Code of the Federation of BiH, particularly economic ones. In determining their guilt, in addition to complex evidence-based actions for the purpose of economic crimes, the law also prescribes direct intent in some places. It is reflected in the knowledge of the responsible person about his personal capacity and knowledge of the illegality of the offense. However, in delicta propria, as most of the economic crimes, the determination of knowledge as a condition for criminal responsibility of the responsible person relativizes the possibility to punish them, which leads to legal insecurity that leads to the consequence leaving unsanctioned responsible person and legal persons in which the responsible persons represent one kind of alter ego. Such de lege lata provisions are the result of dynamic changes in criminal legislation as a result of new forms of crime, criminal offenses and their perpetrators. Therefore, the paper deals with several, seemingly, separate, but necessarily related, issues that need to be matched. Based on the analysis of individual institutes of criminal responsibility, the type of criminal offenses with regard to the perpetrator's circle, and especially the concept of responsible person, the work claims to offer de lege ferenda solutions in relation to the notion of responsible person, but especially the conditions and the way of determining its punishability. The aim is with dogmatic approach to these institutes facilitate the way of finding and detecting the perpetrators of serious criminal offenses from a special part of the Criminal Code, and thereby enabling the purpose of punishment and the purpose of imposing criminal sanctions.

Key words: responsible person, criminal responsibility, direct intent, indirect intent, delicta propria, economic crimes, legal person. 